\title{
THE BOLOGNESE UNIVERSITAS, A UNIVERSITY FOUNDED BY ALIENS
}

\author{
UDC 378.4(450.451)
}

\section{Zoran Dimić}

University of Niš, Faculty of Philosophy, Department of Philosophy, Serbia

\begin{abstract}
This treatise is an attempt to shed some light on the origins of the University of Bologna. The Bolognese University did not appear as a result of someone's deliberate founding act to improve medieval education, but as a result of quite specific cultural, economic and political circumstances. The founding of the university had something to do with the interests and privileges of its students. The City of Bologna was not only a formal framework and just a particular place for the university. The city and the university developed together and influenced and changed each other. At the same time, there was a deep gap between them. Since the majority of the Bolognese students were not from Bologna, but from various Italian and European cities, we can say that the majority of the law students in Bologna were alliens. Since most of the students found themselves in a precarious legal situation, being a Bolognese student had its disadvantages. In order to protect themselves against all of the disadvantages, the students first banded together in "nations" according to their ethnic and geographical origins, and later on into two universitates. In the simplest terms, we can argue that universities were originally the guilds of aliens, i.e. the corporations of foreign students. United in such a way, they could bargain more effectively with the city government, they could negotiate better rents and books prices. From the very beginning of its history, the European university was not only exposed to the political context of the cities and states, but to the economic circumstances too. The outcome of this strong collision was a long history of alien secession and migration to other cities, where they founded new universities. It was a way to spread the idea of the university and education in the Middle Ages.
\end{abstract}

Key words: University of Bologna, origin, nations, universitas, privileges, migrations.

Received February 10, 2017 / Accepted March 4, 2017

Corresponding author: Zoran Dimić

University of Niš, Faculty of Philosophy, Ćirila i Metodija 2, 18000 Niš, Serbia

E-mail: zoran.dimic@ filfak.ni.ac.rs 


\section{INTRODUCTION}

Whatever side we take in arguing about the origins of contemporary universities, the motives for founding the first medieval university, the University of Bologna, appear to be quite unexpected. This treatise is an attempt to shed some light on these motives, although the early history of the University of Bologna appears to be pretty obscure. According to some scholars, contemporary universities are exclusively medieval products. ${ }^{1}$ Chronologically speaking there were no universities before the Middle Ages. The medieval institutions which were founded in Bologna, Padua, Paris, Oxford, Cambridge, etc., at the end of 11th and later during 12th, 13th and 14th centuries, were the first institutions of higher learning in the history of European culture and civilization. These are the first particular schools which deserve the precious name of 'universities'. Having stated this, there were at the same time some very well-known philosophers and scholars familiar with the idea of higher learning who name Plato's Academy as the first university. ${ }^{2}$ The argumentation of both sides is quite different. The first side insisted on formal organization, official licenses, internal divisions, academic titles and departmental structure of medieval universities. These were not the characteristics of ancient schools (Curtius 1947, 64). The other group of scholars emphasized the process of research and specific methodology, which were the main educational and teaching tasks of each of the members of the Academy, no matter whether one was a "scholarch (head of the school)" or a "mathetes (student)". Bearing in mind the limited importance of this problem which is mainly based on its exclusive historical meaning, one might even be led to wonder why it is so essential to know which university was the first one to be founded, we would like to present a completely different issue here.

We wish to refocus the question from the polemic over which university was the first one to the subjectivity of the founders of the university as an institution. Namely, we wish to explore the role of university students and professors. In other words, as it will be demonstrated below, we want to move the focus to the actual historical founders of the first universities, the Bolognese students.

\section{REAL FOUNDERS}

Whenever we talk about the origins and essence of the universities in the Middle Ages we are actually facing many prejudices and preconceived notions. One of the most common is to name the Church as the direct founder of all medieval universities which, in reality, does not correspond to the historical facts. In addition, the first universities did not appear as a result of someone's deliberate founding act aiming at improving medieval education, but they emerged as a result of a certain set of cultural, economic and political

\footnotetext{
${ }^{1}$ Concerning the origin of contemporary universities in the western world there are a few approaches. Curtis argues "Unsere Universitäten sind eine originale Schöpfung des Mittelalters” („Our universities are original product of Middle Age") and "such communities did not existed anywhere in the Antiquity" (translated by the author), (Curtius 1947, 64) Similarly, Haskins claims there is no continuity between ancient schools and medieval universities: "In all these matters we are the heirs and successors, not of Athens and Alexandria, but of Paris and Bologna." (Haskins 1923, 3) On the other hand, Marrou is inclined to accept the educational centers from $4^{\text {th }}$ century A.D. in Alexandria, Beirut, Antioch, Constantinople and Athens as "universities" (Marrou 1948, 320).

${ }^{2}$ Heidegger and Jaeger implicitly consider ancient philosophical schools the first universities. (Heidegger 1990, 1-16; Jaeger 1960, 239)
} 
circumstances (Sorbelli 1944, 14-19; Rashdall 1895, 273; Simon 1932, 7). In order to give the best proof we wish to mention that it must be kept in mind that we know today neither the precise dates of the establishment of medieval universities nor the official founders themselves. No particular name is connected with the founding of the University of Bologna, for example. Haskins clearly explains: "It is hard for the modern world, to realize that many things (universities) had no founder or fixed date of beginning but instead "just grew", arising slowly and silently without definite record...the beginning of the oldest universities are obscure and often uncertain, so that we must content ourselves sometimes with very general statement" (Haskins 1923, 7).

Indeed, what can we know of the circumstances under which the first universities sprung up? The culture of the late $11^{\text {th }}$ century was strongly influenced by antiquity. ${ }^{3}$ Since the beginning of the $12^{\text {th }}$ century, cathedral schools began to bloom. The situation in schools depended first and foremost on the principal (scholasticus) and his individual initiative. As more space for individuality was allowed, the competition among different schools increased and thus the quality of the instruction improved. The "intellectual renaissance" in France opened new possibilities in different fields of the Church and culture. The "rich spiritual life" (ein reiches geistiges Leben) provided good soil for the "dominance of scholasticism" (Grabmann 1957, 3). The University of Paris was founded under such circumstances. This university was dominated by theology. Without any doubt, its central figure was Pierre Abelard. ${ }^{4}$ Just like many other medieval universities, the University of Paris was run from the top down. This university was founded and funded by the Church, and the professors and students were under strict regulations and control of the university authority (Moulin 1992, 210-219; Rashdall 1895, 50-54).

The University of Bologna appeared to develop in a completely different way. ${ }^{5}$ To understand the reasons for the founding of the University of Bologna, it is not enough to take into consideration the intellectual and educational life of medieval Italy. The progress of urban life in medieval cities and the development of trade led to an increased demand for knowledge and education (Simon 1932, 6-7; Sorbelli, 1944, 16-19, 20-29). Particularly the field of law and medicine had become very desirable. ${ }^{6}$ A large number of young people were coming to the big cities in search of knowledge, although primarily to graduate at the university and obtain better social status. The atmosphere of re-growth of enthusiasm for knowledge is the immediate context and background of the founding of the first medieval universities. Knowledge in the field of law was most in demand at that time. The Church and local governors were seeking skilled people who would run the administration. The merchants and ordinary citizens needed somebody who could draw

\footnotetext{
${ }^{3}$ All of these circumstances are described in the best way by Martin Grabmann in his capital work Die Geschichte der scholastischen Methode (Grabmann 1957, 1-9; 59-64)

${ }^{4}$ On the importance of Pierre Abelard for the development of methods of instruction at University of Paris see in details: Grabmann 1957, 168-229. Concerning the development of scholastic theology at Paris around 1200 see as well: Colish 2011, 29-51)

${ }^{5}$ Without any doubt, the best account in English of the University of Bologna is Hastings Rashdalll The Universities of Europe in the Middle Age. See Rashdall 1895, 87-267. At the same time, the best account in Italian is the book Storia della Università di Bologna, vol. I. by Italian historian Albano Sorbelli. Among the relatively recent books, we draw your attention to the Antonio I.Pini treatise, Studio, università e città nel medioevo bolognese. In contrast to the aforementioned books, our goal is not here to deal with the history of the University of Bologna. We just want to draw your attention on some specific details which primarily don't matter the problems of teaching and education.

${ }^{6}$ See about the social and professional position of Doctor of Law: Rashdall 1895, 127.
} 
up a contract of a sale or write a deed. Equally, throughout Italian cities the newly discovered texts of Roman law were copied and studied (Sorbelli 1944, 61-64; Berman 1983 , 122). The tradition of studying Roman law in this region became very strong (Rashdall 1895, 100-103).

Nearing the end of the $11^{\text {th }}$ century, Bologna was a center of the intellectual and cultural life in Central Italy. Its good location, at which all the great lines of communication between the northern entrances to Italy and its center converge, enabled Bologna to be the best place for a meeting between students of Italy and students from beyond the Alps. As it was a town bordering different regions (Lombardy, Tuscany, The March of Verona, etc.), it was an ideal place where people from different cities and nations could meet each other. Even earlier, by the year 1000 A.D. Bologna was famous for its School of Liberal Arts. ${ }^{7}$ Students would come to Bologna from various Italian cities to study law with famous teachers. A significant number of the students were from the rest of Europe as well. They were especially attracted by one particular teacher, named Guarnerius but known historically as Irnerius, a Bolognese citizen by birth, who began to teach in Bologna by the end of $11^{\text {th }}$ century. ${ }^{8}$ In the course of time many other teachers appeared. However it must be made clear that during the professionally active years of Irnerius (1100-1130), no such thing as the University of Bologna existed.

The process of forming a "class" was straightforward. The students would hire a professor for a year according to his reputation. Together with their professors they formed a societas of professors and students, a legal form very well known in Roman law. What we wish to emphasize here is that it was an altogether completely private initiative from both sides. The students wanted to gain knowledge and they were ready to pay for it. The professors had something to offer and they earned money for it. Their relationship was not regulated and controlled by any kind of institution or authority. At that time the professors were not organized into any kind of institution. Each one operated as a freelancer and offered courses that the "market" of students demanded. If a professor was not good at teaching or charged too much, the students would abandon him and search for another one. We could say that in a certain way the professors had to compete for their students. Since the students were the ones who were paying, we can fairly argue that they had a significant advantage in that first educational community in Bologna. It was how the teaching of law in Bologna begun. Apart from the societas of professors and students, (which was just a legal framework for teaching), at this point in the history of the University of Bologna there still was no educational institution to speak of.

Although there has always been an inherent prejudice in the human mind to ascribe the origin of an important institution to a great man, the Bologna University was founded neither by Irnerius nor by Theodosius II (Pini 2005, 74-75; Rashdall 1895, 145). Besides, it did not even have a Charter of Foundation, which would be a commonplace practice associated with the universities founded later on during the Middle Ages and in particular in modern times. As far as we know, Irnerius and the other professors were private teachers without any kind of higher authorization. The first document similar to a legal Charter, the Authentic Habita, was given by the Emperor Frederick Barbarossa in 1158 . It may be considered a kind of implicit recognition, but not the Charter of Foundation

\footnotetext{
${ }^{7}$ About the importance and popularity all over Europe of the Bologna as a School of Liberal Arts, see: Rashdall 1895, 109-110.

${ }^{8}$ About very important role of Irnerius in the history of University of Bologna, see: Rashdall 1895, 81-128; Sorbelli 1944, 35-42).
} 
(Rashdall 1895, 146). Its purpose was intended for the benefit of the law students of Bologna, who accepted to migrate voluntarily "per amore della scienza" (for the love of science) (Pini 2005, 38). We still cannot consider it an official recognition of the University. Formally written as the general privileges proffered to all students in the Lombard Kingdom, it is, first of all, a kind of proof that the medieval emperors and governors were quite inclined to provide privileges in the interests of a new class, the class of students. We consider it extremely important to highlight that the city of Bologna and its government were not mentioned at all in this Charter.

We now come to the most important point. The founding of universities in the Middle Ages had something to do with the interests and privileges of the students. Why, we may ask, did the Emperor want to take the scholars under his protection? Or, we could pose this question in another way: why would the scholars wish to be protected by the authorities? If we want to properly understand the reasons for the founding of the University of Bologna, we have to now turn to some historical facts that actually had nothing to do with teaching and education. Firstly, given the early history of the University of Bologna, we can clearly notice how important the relationship with the city was for the University. The City of Bologna was not only a formal framework or just a particular location for the university. The city and the university were developing together, influencing and changing each other. At the same time, there was a deep gap between them. The "soul" of both was very fragile and dependent on the other. This impression is enhanced if we take into account the importance and continuity of urban life in North Italian cities and its influence over education in general (Rashdall 1936, 95-96). While in France all intellectual life was developed in the religious cloisters or in schools which were part of the latter, in Italy it was connected more to the vigorous urban life, which traced its origin to the old Roman municipal system. Since it is not a subject of this paper and we will not go into detail here, we wish to shortly stress this historical fact that was of great importance for the founding of the University of Bologna; namely, that the revival of intellectual life in Bologna and other Italian cities took a political, or at least a civil direction. If we take in consideration the secular or temporal character of the Bolognese student, we might trace the core of that most characteristic of Bolognese institutions, to be the Student-University, something that was in a number of ways the very opposite of the University of Paris.

\section{THE BOLOGNESE ALIENS FOREIGNERS}

However, we have to pay particular attention to another non-educational, historical fact. Since the majority of the Bolognese students were not from Bologna, but from various Italian and European cities, we can say that the majority of law students in Bologna were aliens. Taking this into consideration, according to some accounts (Sorbelli 1944, 209), the number of Bolognese students could, at any time in the $12^{\text {th }}$ and $13^{\text {th }}$ centuries, be around 10,000, we can conclude that the city of Bologna was full of foreign students. The Bolognese aliens experienced many kinds of problems within the city and related to teaching. Since most of the students found themselves in a precarious legal situation, it would be fair to say that being a Bolognese student had its significant disadvantages. One of the widespread disabilities of the Bolognese aliens was responsibility for the debts of their fellow countrymen. Each foreign student could be 
liable for the debts of his countrymen, just because they originated from the same city or country, even if they did not know each other. For example, if Peter, a merchant from England, owed money to Marco, a Bolognese citizen, and Peter left town, then innocent student Paul from England, could be required by Bolognese law to pay Marco the money owned by Peter simply by virtue of being English (Berman 1983, 123).

The Bolognese aliens experienced several other kinds of disadvantages. In order to understand them, we must take a look at the political circumstances of the City of Bologna at that time. The political conception of citizenship in the Italian cities was completely different from the modern one. Citizenship and all the rights it implied derived from an accident of domicile. The citizens of one town had no civil rights in another. For example, a Bolognese student from Ravenna had no civil rights in Bologna. So there was one law for the citizen of Bologna and another law for aliens (Rashdall 1895, 152). If we wish to put it more precisely, we have to say that there was no law for foreign students. As somebody who was essentially without rights, aliens were exposed to all kinds of unfair treatment and hazards: high prices of lodging, teaching and books, lack of renting contracts, a real possibility for forced exile, etc. Because they were far away from their homes, they had to pay for all different kinds of services. Since most of them were not wealthy, they encountered numerous problems to cover all their living costs.

In short this is the context in which the first universities appeared. In order to protect themselves against all of these disadvantages, the students first banded together in "nations" according to their ethnic and geographical origin (Sorbelli 1944, 150-158; Moulin 1992, 106-115). The first nations were called: the Franks, Provencals, Picards, Alemans, Angles, Spaniards, etc. There were more than twenty nations at the start, which finally united into two corporate bodies, or guilds. Around the middle of the $13^{\text {th }}$ century in Bologna there were two different associations of students. The first one included all the students from the north of the Alps (Citramontanorum), and the second one of all those from the south of the Alps (Ultramontanorum). Each of these two corporate bodies of aliens was called universitas, according to the term of Roman law, equivalent to today's terminology as corporation or association. In the simplest terms, we can argue that the universities were originally the guilds of aliens, i.e. corporations of foreign students.

How did it come about that in the process of the founding of the first universities being an alien was more important than being a student? How was it that during the early history of the first medieval university, the University of Bologna, a non-educational factor was more important than many other factors that were originally educational in nature? In order to explain this well, we wish to point out the fact that the first universitas in Bologna was not founded in order to improve teaching or any other educational aspect of scholarship. The immediate motive for the incorporating of Bolognese aliens into the universitas had nothing to do with teaching and education. It had something to do with being treated as an alien and not being in the circle of the protected: in order to avoid rejection from the group of "real students", the Bolognese aliens decided to stick together and thereby acquire some mutual assurance and protection. United in such a way, they could bargain more effectively with the city government, they could negotiate better rent and books prices. If any of them required some kind of assistance, for instance, in paying his unknown countryman's debts, the other members would help him by collecting money. By pledging contributions to the group for this purpose, a student could expect help for himself in a time of need. 
It appears that the aliens' motives for access to the "nations" and universitas was pretty pragmatic. As a matter of fact it primarily concerned their personal interest within the wider community of the city of Bologna and in general terms as well. On this particular point, concerning the motives of non-Bolognese students to found universities, Rashdall and Berman emphasize the problem of citizenship and lack of rights (Rashdall 1895, 152; Berman 1983, 123). Rashdall considers the founding of universitas as "an attempt...to create for themselves an artificial citizenship in place of the natural citizenship". For Berman "the virtues of incorporation were obvious to the students of Bologna, teenagers who by medieval standards were mature young men ready for an active political life". The reason for founding the first university was political and it centered first of all on the lack of political rights. We find, however, that the political context was very important for the creation of the first medieval university as well, but we do not find it to be the most decisive one.

\section{LEGAL, SOCIAL AND ECONOMIC INTERESTS}

Generally speaking, we can explain the essence of the Middle Ages in terms of privileges rather than in terms of human rights better. It was a period of monarchical emperors and governors who were absolute sovereigns. They were the ones who made decisions about the granting of rights. They could rescind rights to some particular individuals or cities as fast as they had granted them. When we are speaking about rights in the Middle Ages, we are not actually speaking about laws that buttress and underpin them, but about charters and bulls. In that sense, we will better understand the aliens' motives for founding a university, if we turn once again to the very complex relationship between the non-Bolognese students and the City of Bologna. First of all we must always bear in mind that studying was expensive, particularly for foreigners (Moulin 1992, 115117; Pini 2005, 189-210). In addition it is important to note that the students were the ones who were paying. They were paying professors to teach, they were paying them for books as well, but they were also paying the citizens of Bologna for all of kinds of services (lodging, food, drinks, clothes, etc.). As we saw earlier, they also had to pay for other people's debts. This was of enormous importance to the commercial welfare of the City of Bologna (Pini 2005, 247-265). This may explain why there was always an ultimate willingness of the municipality to recognize the community of aliens. But it did not occur without a permanent struggle.

Before we say anything more about this struggle, we have to mention the general inclination of $11^{\text {th }}$ century Europe for associating into different kinds of corporations: guilds, hansas, universitas, etc. The nations and universitas that were established in Bologna were just a particular kind of guild, flourishing in all European cities. The rapid development of handcrafting, mining and trading enabled many more ordinary people than earlier to try to improve their lives. These people were not part of the nobility. After a long period of experiencing misery and poverty they just wanted to take a chance and try to improve their quality of living. Not being part of the privileged classes, by joining the guilds, new craftsmen and merchants were trying to support their businesses and protect their interests. In the particular case of Bologna, according to Roman law, the legal existence of a guild was allowed without any kind of formal authorization of the city (Rashdall 1895, 153). If you wanted to establish an association, it was necessary to 
have at least three members. You did not have to provide a contract, it was just enough to take an oath. But of course an oath and perjury had completely different significance in the Middle Ages than they have today. Perjury was a mortal sin. Consequently a large amount of political power started to be accumulated within the guilds. Concerning political and social power, these kinds of corporations began to compete with the city itself. What is more important for our argument, since we do think that the political aspect is not essential under the circumstances, we have to emphasize that membership in a guild was crucial to personal welfare and security.

If the students, that is to say, the Bolognese aliens, had not organized themselves into universitas, they could not have obtained any privileges in order to protect their interests within the foreign political and educational context they were experiencing in the City of Bologna. That is why we prefer to use the term personal motive, concerning the analysis of the immediate cause for the founding of the Bolognese University, instead of reason. We cannot develop that argumentation here, because it is not the subject of this text, but we are deeply convinced that during the whole history of university studies, it always had something to do with the person itself. No matter what the conditions were, or what political or economic context education took place in, always, first and foremost, it concerned the personality of the students and of the professors. It is not some abstract and imaginary entity who is studying, and it is not some social or economic intangible power either. It is a living beings who are doing the studying and they always have some personal motives and interests for studying. By using the terms motives and interests we want to emphasize in this context what in Rashdall's and Berman's writings was out of focus: the economic aspects of the Bolognese university establishment. From the very beginning of its history, the European university was not only exposed to the political context of the cities and states, but to the economic circumstances too.

\section{THE GAP}

Let us now turn to the above-mentioned struggle between the Bolognese aliens and the City. After all that has been said, it is obvious that the original reasons for the founding of the Bolognese University must be sought in the personal experience of the non-Bolognese students. We have to shed some light on their particular emotions and primarily on the feeling of disadvantage and disenfranchisement that is typical for the inhuman treatment of persons. The immediate reason for these particular personal experiences and emotions was placed in the gap that existed between students and the City. Once the universitas had been established, the students had reached the means of very effective collective bargaining with the government of the City. That is in fact the exact way the students referred to the City, they were bargaining with it, that is to say, they established a relation with the city through the usage of economic terms. In order to gain what they were searching for from the City government, for instance lower prices of lodging, the students were able to exercise considerable leverage. Namely, if the students would make a decision to go on "strike" and leave the City, the professors would follow their paying clients and the City would lose a huge source of income. The Bolognese Government did not have any problem conceding to the universities of aliens what was conceded to other guilds as well, but in certain respects the universities demanded more than the city normally allowed the guilds. 
Therefore it is now possible to realize all the complexity of the position of a foreign student at that time. Yet, since a student is not a part of the city, he does not respect it as normal citizens do. Even more so, the alien tries to destroy the city by avoiding its laws and rules. Contrarily to other guilds (for instance guilds of craftsmen or merchants, which were composed of legal citizens of Bologna who never thought of disputing the authority of the city government because they would risk losing their property and political status), aliens did not have anything to lose. The guilds of students actually consisted of "aliens who refused to recognize the authority of the city in which they lived when it conflicted with the allegiance which they had sworn" to their own universitas (Rashdall 1895, 170). By threatening to leave the city, aliens would place enormous pressure on the city government. In many cases, they even succeeded in changing the city statute in their favor. ${ }^{9}$ The power of secession and migration was the strongest instrument of warfare against the city government. From the city's point of view this unfair advantage was unacceptable. The city sought to 'defang' this unfair advantage of the students' guild to prevent it from developing further, without being dependent on the good will of an alien guild. The outcome of this strong collision was a long history of alien secessions and migrations to other cities, where they founded new universities. Particularly at the beginning of the $13^{\text {th }}$ century the City of Bologna faced frequent student migrations. Unsatisfied with their treatment, aliens started negotiations with other cities for the transfer of the university to different locations. In this way the universitas of Vicenza appeared in 1204, followed by Arezzo in 1215, Padua in 1222, etc. In the beginning, the professors would follow their clients, but, in time, the city itself became more strict and started to impose penalties for those "who shall without permission of the city magistrates leave Bologna for the purpose of lecturing elsewhere" (Rashdall 1895, 173). It took a long time before the university got its first Statute (1317). It is not our goal to expose in this argument the long and difficult history of conflicts between the non-Bolognese students and the City of Bologna. With time new collisions appeared, among the professors, and between students and the city government. This chaotic setup was eventually brought to an end when the City took over and began paying professors directly from tax revenues. It was the start of a new era. The University of Bologna became a publicly funded institution. But, apart from the clients, nothing had changed. Instead of by the students, professors were now paid by the city government. Instead of being dependent on the students, they became dependent on the city government. The one who pays still dictates the "rules of the game". Power over the university and everything that went on within the walls of the educational institution moved from Bolognese students to Bolognese politicians.

\section{CONCLUSION}

To conclude this argument, we would like to impress upon the reader that the most convincing evidence for the depth of the above-mentioned gap was the simple historical fact that native Bolognese students were not members of the universitas. The students

\footnotetext{
${ }^{9}$ For instance, it happened in Padua, where the university was founded by the students who migrated from Bologna. After the pressure they made over the government, the statute was changed, so "the punishment against anyone who cites a scholar before the City Magistrates was denounced...The same Statutes enact that if a householder refuses to execute repairs after fifteen days' notice, the tenant is to repair, and deduct the expense form the rent" (Rashdall 1895, 170)
} 
who were from Bologna did not have the motives to struggle for themselves, because they already had all the privileges they needed. Their interests were already well protected. Paradoxically, we could say that the university probably would not have been invented and founded, if the students of the University of Bologna had only been Bolognese citizens. If it had only been up to the students from Bologna, we would not have universities as we know them today: hence the importance of emphasizing the role of aliens. In addition, we would like to highlight the following outcomes of our research. The founding of the University of Bologna had first and foremost something to do with the interests and privileges of the students. In this context, the relationship of the students to the city itself had crucial importance for the founding of the University of Bologna. The Universitas of Bologna consisted originally of guilds of aliens, i.e. the corporations of foreign students. So, the first university, the Bolognese universitas, consisted of nonBolognese students. With time, within the student's guilds, a large amount of political power started to be amassed. In relation to this, the political and social power accumulated by these corporations began to compete with the city itself. Therefore, within such a foreign political context, if the students, that is to say, the Bolognese aliens, had not organized themselves into universitas, they could not have obtained any kind of privileges in order to protect their interests. By using the terms motives and interests we wish to point out the economic aspects of the establishment of the Bolognese University. From the very beginning of its history, the European university was not only exposed to the political context of the cities and states, but also to the much larger economic conditions.

Finally, we claim forcefully that the original reasons for the founding of the Bolognese University must be sought in the personal experience of the non-Bolognese students. The immediate cause for these particular personal experiences and emotions can be found in the gap that existed between the aliens and the city. However, a black and white approach to the essence of the alien experience will not help us to understand the problem. The aliens invented their own "city", but at the same time they were very hostile to the real City of Bologna. Here we face all the complexity of somebody who is an alien. Since he is not part of the city, he does not respect it. However, aliens at university are not just one historical fact. Each of us, members of the university community, no matter whether we are students or professors, is divided into two worlds, the one within the university and the other outside of the university. "The university walls", more or less visible, that we have built during the history into the university tradition, has protected us from the outside world, but at the same time it has limited us. Our destiny is to live torn between intra and extra-muros worlds. In this way, separation and migrations have been part of the history of university throughout time. It is not easy to destroy or "move" that muros, but at least we can wonder about who built them and why they are there, still around us.

Acknowledgement: The paper is a part of the research done within the project "Universities in the Middle Age and early Modern Europe", which I realized as a Erasmus Mundus SIGMA A2 Postdoc holder at the Università degli studi di Milano. The authors would like to thank to his supervisor prof. Stefano Simonetta from the Department of Philosophy. 


\section{REFERENCES}

Berman, Harold J. Low and Revolution. Cambridge/Massachusetts/London: Harvard University Press, 1983. Curtius, Robert E. Europäische Literatur und leteinisches Mittelalter. Bern/München: Francke, 1947.

Colisch, Marcia L. "Scholastic Theology at Paris around 1200". In Crossing Boundaries at Medieval Universities, edited by Spencer E. Young, 29-51. Leiden/Boston: Brill, 2011.

Grabmann, Martin. Die geschicthe der scholastischen Methode I-II. Berlin: Akademie Verlag, 1957.

Romano, Andrea, ed. Gli Statuti universitari. Bologna: CLUEB, 2007.

Heidegger, Martin. Die Selbstbehauptung der deutschen Universität, Das Rektorat 1933/34. Frankfurt a/M: Vittorio Klostermann, 1990.

Haskins, Charles H. The Rise of Universities. New York: Henry Hold and Company, 1923.

Jaeger, Werner. „Die Griechen und das philosophische Lebensideal“. In Humanistische Reden und Vorträge. Berlin: Walter de Gruyter and CO, 1960.

Pini, Antonio I. Studio, università e città nel medioevo bolognese. Bologna: CLUEB, 2005.

Rashdall, Hastings. The Universities of Europe in the Middle Ages, vol. I. Oxford: Oxford University Press, 1895 .

Marrou, Henri-Irenee. Histoire de l'éducation dans l'Antiquité. vol. I. Paris: Éditions du Seuil, 1948.

Moulin, Leo. La vita degli studenti nel medievo. Milan: Jaca book, 1992.

Simon, Paul. Die Idee der mittelatersichen Universität und ihre Geschichte. Tubingen: Verlag von J.C.B.Mohr (Paul Siebeck), 1932.

Sorbelli, Albano. Storia della Università di Bologna, vol. 1. Bologna: Il Medioevo: Secc.XL-XV, 1944.

\section{BOLONJSKI UNIVERSITAS - UNIVERZITET KOJEG SU OSNOVALI STRANCI}

Ovaj rad predstavlja pokušaj da se osvetli poreklo Univerziteta u Bolonji. Bolonjski univerzitet se nije pojavio kao rezultat nečije namere da se unapredi obrazovanje u srednjem veku, već kao rezultat sasvim specifičnih kulturnih, ekonomskih i političkih okolnosti. Osnivanje ovog univerziteta se ticalo interesa i privilegija samih studenata. Grad Bolonja nije bio samo formalni okvir i mesto za univerzitet. Grad i univerziet su se zajedno razvijali, međusobno uticali i menjali jedan drugog. Istovremeno, između njih je postojao veliki jaz. Budući da većina studenata u Bolonji nije bila iz Bolonje, već iz različitih italijanskih i evropskih gradova, slobodno možemo reći da su većina studenata prava u Bolonji zapravo bili stranci. S obzirom da se većina studenata nalazila u pravno nesigurnoj situaciji, biti studentom u Bolonji značilo je ujedno suočiti se sa mnoštvo hendikepa. Da bi zaštitili sebe od svega toga, studeti su se najpre udruživali u „nacije“, u skladu sa svojim etničkih $i$ geografskim poreklom, a od više ,nacija" kasnije su nastajali univerziteti. Najjednostavnije rečeno, mi tvrdimo da su univerziteti izvorno zapravo bili gilde stranaca, tj. udruženja stranih studenata. Ujedinjani na takav način, oni su mogli da bolje pregovaraju sa gradskim vlstima, te da se izbore za niže stanarine ili niže cene knjiga. Od samo početka svoje istorije, evropski univerzitet nije izložen samo političkom kontekstu gradova $i$ država, već se ujedno nalazio u jednom ekonomskom okruženju. Ishod ove jake kolizije zapravo je duga istorija odcepljenja i migracija studenata iz jednih u druge gradove, gde bi osnivali nove univerzitete. To je zapravo bio način na koji se u srednjem veku širila ideja univerziteta i obrazovanja.

Ključne reči: Univerzitet u Bolonji, poreklo, nacije, univerzitet, privilegije, hendikepi, stranci, migracije. 